\title{
The association of eotaxin-2 and eotaxin-3 gene polymorphisms in a Korean population with ulcerative colitis
}

\author{
Young-Ran Park ${ }^{1,5}$, Suck-Chei Choi ${ }^{2}$, \\ Soo-Teik Lee ${ }^{4}$, Kyung-Suk Kim ${ }^{5}$, \\ Soo-Cheon Chae ${ }^{1,6}$ and Hun-Taeg Chung ${ }^{1,3}$ \\ ${ }^{1}$ Genome Research Center for Immune Disorders \\ ${ }^{2}$ Department of Internal Medicine \\ ${ }^{3}$ Department of Microbiology and Immunology \\ Wonkwang University School of Medicine \\ Chonbuk 570-749, Korea \\ ${ }^{4}$ Department of Internal Medicine \\ Chonbuk National University Medical School \\ Chonbuk 560-180, Korea \\ ${ }^{5}$ Institute for Molecular Biology and genetics \\ Division of Biological Sciences \\ Chonbuk National University \\ Chonbuk 561-756, Korea \\ ${ }^{6}$ Corresponding author: Tel, 82-63-850-5665; \\ Fax, 82-63-851-5066; E-mail, chaesc@wonkwang.ac.kr
}

Accepted 6 October 2005

Abbreviations: AHR, airway hyperreactivity; LD, linkage disequilibrium; OR, odds ratios; PCR, polymerase chain reaction; SBE, single-base extension; SNP, single nucleotide polymorphism; UC, ulcerative colitis

\begin{abstract}
The eotaxin gene family (eotaxin, eotaxin-2 and eotaxin-3) have been implicated in the recruitment of eosinophils, basophiles and helper $T$ (Th) 2 lymphocytes that is a central aspect of allergic disease. We previously suggested that Eo2 $+179 T>$ $C$ and Eo2 $+275 C>T$ of the eotaxin-2, and Eo3 + $2497 T>G$ of the eotaxin-3 were significantly as sociated with susceptibility to asthma. To determine whether the single nucleotide polymorphisms (SNPs) of eotaxin-2 and eotaxin-3 gene family are associated with the susceptibility of ulcerative colitis (UC), we analyzed the genotype of 119 patients with $\mathrm{UC}$ and 303 controls using single-base extension (SBE) method. We also calculated the haplotype frequencies among Eo2 $+179 T>C$ and Eo2 $+275 C$ $>T$ of the eotaxin-2 and Eo3 $+2497 T>G$ of the eotaxin-3 in both control and UC patients. The genotype frequency of Eo2 $+179 T>C$ and Eo2 + 275C $>T$ between UC patients and controls were
\end{abstract}

significantly different $(P=0.006$ and 0.022 , respectively). The genotype and allele frequencies of EoA2497T $>G$ in UC patients were not significantly different from those in the controls without UC patients. Our results suggest that $E 02+179 T>C$ and Eo2 $+275 C>T$ of eotaxin-2 might be associated with the susceptibility of UC.

Keywords: colitis ulcerative; inflammatory bowel diseases; polymorphism, single nucleotide

\section{Introduction}

Crohn's disease (CD) and ulcerative colitis (UC) are the two major forms of inflammatory bowel diseases (IBD) in humans (Blumberg et al., 1999). The balance between pro- and anti-inflammatory cytokines secreted by $T$ cells is responsible for both the initiation and perpetuation of IBD. Production of cytokines by lamina propria $\mathrm{CD}^{+} \mathrm{T}$ lymphocytes differs between $C D$ and UC. Whereas $C D$ is associated with increased production of Th1 type cytokines, such as interferon-gamma (IFN- $\gamma$ ) and tumor necrosis factor alpha (TNF- $\alpha$ ), UC is associated with $\mathrm{T}$ cells producing large amounts of the Th2 type cytokine IL-5, but dose not affect IFN- $\gamma$ production (Targan et al., 1995; Fuss et al., 1996; Plevy et al., 1997).

Eotaxin gene family (eotaxin, eotaxin-2 and eotaxin-3) is a CC chemokine that stimulates the migration of eosinophil from the small blood vessels in the lungs by acting on the $\mathrm{CC}$ chemokine receptor CCR3. Whereas the Eotaxin (CCL11) has been identified to be located on chromosome 17q21, Eotaxin-2 (CCL24) and Eotaxin-3 (CCL26) are located on chromosome $7 q 11.23$. The homologues to the eotaxin gene, eotaxin-2 (CCL24) and eotaxin-3 (CCL26) have been identified (Patel et al., 1997; Shinkai et al., 1999) and have similar eosinophilselective properties. While Eotaxin-3 has less potency than Eotaxin and Eotaxin-2 for binding to CCR3 (Kitaura et al., 1999), the all eotaxin genes showed similar range in the chemotaxis efficacies of human eosinophils (Dulkys et al., 2001). All three eotaxin genes have been shown to be associated with eosinophil recruitment in asthma patients. Eotaxin-2 mRNA levels increased in bronchial biopsies taken from atopic and non-atopic asthmatics (Ying et al., 1999). Eotaxin mRNA also contributes to the 
early phase of allergen-induced recruitment of activated eosinophils into the airways of patients with allergic asthma (Brown et al., 1998). In contrast, eotaxin-3 mRNA was dramatically increased $24 \mathrm{~h}$ after allergen challenge (Berkman et al., 2001). This result demonstrates that Eotaxin-3 may mainly act for the eosinophil recruitment in the later stage of asthmatic response. Eotaxin-2 production is differentially regulated in monocytes and macrophages (Watanabe et al., 2002), and Eotaxin-2 and IL-5 cooperatively promoted eosinophil accumulation, IL-13 production, and airway hyper-reactivity (AHR) to methacholine (Yang et al., 2003).

Recently, the single nucleotide polymorphisms (SNPs) in the eotaxin gene family were identified (Shin et al., 2003; Chae et al., 2004). We previously reported that the Eo2 $+179 T>C, E O 2+275 C>T$ of eotaxin-2 and the Eo3 $+2497 T>G$ of eotaxin-3 are significantly associated with susceptibility to asthma, and also demonstrated that the Eo3 $+2497 T>G$ is related to serum total $\mathrm{lg} E$ level, and to the peripheral blood eosinophil counts in asthma patients (Chae et al., 2004). We also suggested that the SNPs of eotaxin-3 might be associated with susceptibility to allergic rhinitis (Chae et al., 2005). UC as well as asthma is generally associated with a disease with strong Th2 type cytokine expression. We analyzed the genomic DNA isolated from 119 UC patients and 303 controls to determine whether polymorphisms of the eotaxin-2 and eotaxin-3 are associated with the susceptibility of UC.

\section{Materials and Methods}

\section{Subjects and DNA samples}

Blood samples and records were obtained from 119 UC (70 males, 49 females) patients and 303 (196 males, 107 females) controls without UC. The mean age of UC patients and controls were $40.7 \mathrm{yrs}$ and 49.7 yrs, respectively. Genomic DNA was extracted from leukocytes in peripheral blood, by a standard phenol-chloroform method, or by using the Puregene ${ }^{\circledR}$ DNA Purification kit (Gentra) according to the manufacturer's instruction. The UC patients were recruited from the outpatient clinic at Wonkwang University Hospital and Chonbuk National University Hospital. Patients were classified into the UC group according to clinical features, endoscopic findings, and histopathologic examinations. The controls without UC were recruited from the general population, and had received comprehensive medical testing at the Wonkwang University Hospital. All subjects in this study were Korean, who lived in the same area.

\section{Polymerase chain reaction (PCR)}

Two primer pairs were used for amplification of the full length of eotaxin-2 and eotaxin-3 genes (Chae et al., 2005). PCR reactions were performed using EX Taq polymerase (TaKaRa, Japan) and using $50 \mathrm{ng}$ total genomic DNA per reaction. Amplification was carried out in a GeneAmp PCR system 9700 thermocycler (Applied Biosystem) at $92^{\circ} \mathrm{C}$ for $1 \mathrm{~min}$, followed by 10 cycles at $92^{\circ} \mathrm{C}$ for $10 \mathrm{~s}, 68^{\circ} \mathrm{C}$ for $45 \mathrm{~s}$, and $68^{\circ} \mathrm{C}$ for $10 \mathrm{~min}$. Then 20 cycles at $92^{\circ} \mathrm{C}$ for 10 $\mathrm{s}, 68^{\circ} \mathrm{C}$ for $45 \mathrm{~s}$ and $68^{\circ} \mathrm{C}$ for $10 \mathrm{~min}$ (with $10 \mathrm{~s}$ incremental increases per cycle) were followed by a final extension at $68^{\circ} \mathrm{C}$ for $7 \mathrm{~min}$. The PCR products purified by PCR purification kit (Millipore) were used as the template DNA for cycle sequencing (Chae et al., 2004).

\section{Genotyping}

Genotyping was performed by single-base extension (SBE) using the ABI Prism ${ }^{\circledR}$ SNaPshot $^{\mathrm{TM}}$ Multiplex kit (Applied Biosystems). The previously used seven SBE primers (Chae et al., 2005) were used in this study for genotyping of eotaxin-2 and eotaxin-3 SNPS in UC patients and controls. The SBE reaction mixture was prepared according to the manufacturer's instructions. The primer extension reaction was performed at $96^{\circ} \mathrm{C}$ for $1 \mathrm{~min}$, followed by 25 cycles at $96^{\circ} \mathrm{C}$ for $10 \mathrm{~s}, 55^{\circ} \mathrm{C}$ for $40 \mathrm{~s}$, and $60^{\circ} \mathrm{C}$ for $30 \mathrm{~s}$. To clean up the primer extension reaction, 1.5 $U$ of CIP (New England BioLabs) was added to the reaction mixture, and the mixture was incubated at $37^{\circ} \mathrm{C}$ for $90 \mathrm{~min}$, followed by $15 \mathrm{~min}$ at $72^{\circ} \mathrm{C}$, to inactivate enzyme The purified extension products were added to Hi-Di formamide (Applied Biosystems) according to the recommendations of the manufacturer. The mixture was incubated at $95^{\circ} \mathrm{C}$ for $5 \mathrm{~min}$, followed by $5 \mathrm{~min}$ on ice, and then electrophoresis was performed, using the ABI Prism 3100 Genetic Analyzer. The results were analyzed using the $A B I$ Prism GeneScan and Genotyper software (Applied Biosystems).

\section{Statistic analysis}

The UC patients and controls were compared using case-control association analyses. The $\chi^{2}$ tests were used to estimate the Hardy-Weinberg equilibrium (HWE). Logistic regression analyses were used to calculate odds ratios (OR) (95\% confidence interval) for SNP sites (Shin et al., 2005). Linkage disequilibrium (LD) analyses by pair-wise comparison of biallelic loci and haplotype, and their frequencies, were constructed with an EM algorithm or Permutation test, with genotyped SNPs. Fisher's exact test or $\chi^{2}$ test from $2 \times 2$ contingency table was applied to 
analyze the comparison of the frequency of discrete variables between unrelated UC patients and unrelated controls. A $P$-value of less than 0.05 was considered to indicate statistical significance.

\section{Results}

We previously identified a total of eight SNPs in the coding and boundary intron region of eotaxin-2 and eotaxin-3 gene; six SNPs in eotaxin-2 gene, and two SNPs in eotaxin-3 gene, and suggested that Eo2 $+179 T>C$ and Eo2 $+275 C>T$ of the eotaxin-2 gene and Eo3 +497T>G of the eotaxin-3 gene were significantly associated with the susceptibility of asthma (Chae et al., 2004). We also analyzed the association between allergic rhinitis patients and controls, and suggested that the Eo2 $+179 T>C$ and Eo2 $+275 C>T$ of the eotaxin-2 gene and Eo3 $+1577 G>A$ and Eo3 $+2497 T>G$ of the eotaxin-3 gene may be associated with susceptibility to allergic rhinitis (Chae et al., 2005). To precisely determine whether these polymorphisms were associated with susceptibility of another allergic disease such as UC in a Korean, we analyzed the genotype and allele frequencies in SNPs of the eotaxin-2 and eotaxin-3 gene by SBE method on genomic DNA samples isolated from 119 unrelated UC patients and 303 unrelated controls without UC. All genotype frequencies were in Hardy-Weinberg equilibrium
(HWE), except Eo2 $+304 A>C$ in UC patients (data not shown). We analyzed LDs among these SNPs of eotaxin-2 and eotaxin-3 gene, and found that an absolute LDs ( $\left|D^{\prime}\right|=1$ and $d^{2}=1$ ) was observed between the Eo3 $+77 C>T$ and Eo3 $+1577 G>A$ of eotaxin-3 gene. The strong LDs $\left(\left|D^{\prime}\right|=0.926\right)$ between the Eo2 $+179 T>C$ and EO2 $+275 C>T$ of eotaxin-2 was also observed. Interestingly, the strong LDs between the Eo2 $+179 T>C$ of eotaxin-2 gene and Eo3 $+1577 G>A$ of eotaxin-3 gene as well as between the Eo2 $+275 C>T$ of eotaxin-2 gene and Eo3 $+2497 T>G$ of eotaxin-3 gene were observed $\left(\left|D^{\prime}\right|=0.994\right.$ and 0.999 , respectively). These results prove our previous suggestion that eotaxin-2 and eotaxin-3 might be same block because these genes are closely located on the same chromosome at distance of about $40 \mathrm{~kb}$ (Chae et al., 2004).

The $P$ values of each polymorphism were analyzed between the UC patients and the controls (Table 1 and 2). Although the allele frequency of Eo2 $+179 T>C$ and Eo2 $+275 C>T$ between UC patients and controls was not significantly different $(P=$ 1.000 and 0.679 , respectively), the both genotype frequencies of Eo2 $+179 T>C$ and $E o 2+275 C>T$ between UC patients and controls were significantly associated $(P=0.006$ and 0.022 , respectively). The genotype frequencies of Eo2 $+179 T>C$ and Eo2 $+275 C>T$ in UC patients were significantly different from those in non-UC controls, however all the odds ratios $(\mathrm{OR})(95 \% \mathrm{Cl})$ between UC patients and

Table 1. Genotype and allele frequencies of the eotaxin-2 SNPs between UC patients and controls.

\begin{tabular}{|c|c|c|c|c|c|}
\hline Position $^{a}$ & $\begin{array}{l}\text { Genotype/ } \\
\text { Allele }\end{array}$ & $\begin{array}{l}\text { Control } \\
n(\%)\end{array}$ & $\begin{array}{l}\text { UC } \\
n(\%)\end{array}$ & $\begin{array}{c}\mathrm{OR}^{\mathrm{b}} \\
(95 \% \quad \mathrm{Cl})^{\mathrm{b}}\end{array}$ & $P^{\mathrm{C}}$ \\
\hline \multirow{5}{*}{$\begin{array}{c}E o 2+179 T>C \\
(\text { rs2302004) }\end{array}$} & $\mathrm{CC}$ & $105(44.5)$ & $43(36.1)$ & 1.00 & \multirow[t]{3}{*}{0.006} \\
\hline & $\mathrm{TC}$ & 94 (39.8) & $67(56.3)$ & $1.74(1.08-2.79)$ & \\
\hline & $\mathrm{TT}$ & $37(15.7)$ & $9(7.6)$ & $0.59(0.24-1.34)$ & \\
\hline & $\mathrm{C}$ & $304(64.4)$ & $153(64.3)$ & 1.00 & \multirow[t]{2}{*}{1.000} \\
\hline & $\mathrm{T}$ & $168(35.6)$ & $85(35.7)$ & $1.01(0.73-1.39)$ & \\
\hline \multirow{5}{*}{$\begin{array}{c}E o 2+275 C>T \\
(\mathrm{rs} 2302005)\end{array}$} & $\mathrm{TT}$ & $103(44.4)$ & 47 (39.5) & 1.00 & \multirow[t]{3}{*}{0.022} \\
\hline & $\mathrm{CT}$ & $90(38.8)$ & $62(52.1)$ & $1.51(0.94-2.42)$ & \\
\hline & $\mathrm{CC}$ & $39(16.8)$ & $10(8.4)$ & $0.56(0.26-1.22)$ & \\
\hline & $\mathrm{T}$ & $296(63.8)$ & $156(65.6)$ & 1.00 & \multirow[t]{2}{*}{0.679} \\
\hline & C & $168(36.2)$ & $82(34.4)$ & $0.93(0.67-1.29)$ & \\
\hline \multirow{5}{*}{$\begin{array}{c}E 02+304 A>C \\
(\mathrm{rs} 2302006)\end{array}$} & $\mathrm{CC}$ & $61(26.1)$ & $23(19.3)$ & 1.00 & \multirow[t]{3}{*}{0.063} \\
\hline & $A C$ & $129(55.1)$ & 81 (68.1) & $1.67(0.96-2.90)$ & \\
\hline & AA & 44 (18.8) & 15 (12.6) & $0.90(0.42-1.93)$ & \\
\hline & C & 251 (53.6) & $127(53.4)$ & 1.00 & \multirow[t]{2}{*}{1.000} \\
\hline & $A$ & $217(46.4)$ & 111 (46.6) & $1.01(0.74-1.38)$ & \\
\hline
\end{tabular}

${ }^{a}$ Calculated from the translation start site, ${ }^{b}$ Logistic regression analyses were used for calculating $\mathrm{OR}\left(95 \% \mathrm{Cl}\right.$; confidence interval), ${ }^{9}$ Value was determined by Fisher's exact test or $\chi^{2}$ test from $2 \times 2$ contingency table. 
controls were not significant except the TC genotype $(\mathrm{OR}=1.74(1.08-2.79))$ in Eo2 +179T $>C$ (Table 1). The genotype and allele frequencies of Eo3 $+2497 T>G$ in UC patients were not significantly different from those in the controls $(P=0.190$ and $P$ $=0.096$, respectively). Our present results suggest that eotaxin-2 might be associated with susceptibility to UC. We previously reported that Eo2 $+179 T>C$ and Eo2 $+275 C>T$ of the eotaxin-2 were significantly associated with the susceptibility of asthma as well as allergic rhinitis (Chae et al., 2004; Chae et al., 2005). These results led us to think that the polymorphism of eotaxin-2 was associated with allergic diseases such as asthma, allergic rhinitis and UC.

We calculated the haplotype frequencies between the Eo2 $+179 T>C$ and Eo2 $+275 C>T$ of eotaxin-2 in controls and UC patients. Four haplotypes were identified with two major haplotypes explaining more than $92 \%$ of distribution, and there was no significant difference in haplotype frequencies in both group (data not shown). We also calculated the haplotype frequencies among the Eo2 +179T>C and Eo2 $+275 C>T$ of eotaxin-2 gene and the Eo3

Table 2. Genotype and allele frequencies in the eotaxin-3 SNPs between UC patients and controls.

\begin{tabular}{|c|c|c|c|c|c|}
\hline Position $^{a}$ & Genotype & $\begin{array}{l}\text { Control } \\
n(\%)\end{array}$ & $\begin{array}{l}\text { UC } \\
n(\%)\end{array}$ & $\begin{array}{c}\mathrm{OR}^{\mathrm{b}} \\
(95 \% \quad \mathrm{Cl})^{\mathrm{b}}\end{array}$ & $P^{c}$ \\
\hline \multirow{5}{*}{$\begin{array}{c}\text { Eo3 }+77 C>T \\
(\text { rs2240478) }\end{array}$} & $\mathrm{CC}$ & $111(37.8)$ & $44(37.0)$ & 1.00 & \multirow[t]{3}{*}{0.803} \\
\hline & $\mathrm{CT}$ & $148(50.3)$ & $58(48.7)$ & $0.99(0.62-1.57)$ & \\
\hline & $\mathrm{TT}$ & 35 (11.9) & $17(14.3)$ & $1.23(0.62-2.41)$ & \\
\hline & C & $370(62.9)$ & $146(61.3)$ & 1.00 & \multirow[t]{2}{*}{0.692} \\
\hline & $\mathrm{T}$ & $218(37.1)$ & $92(38.7)$ & $1.07(0.78-1.46)$ & \\
\hline \multirow{5}{*}{ Eo3 $+1577 G>A$} & GG & $266(87.8)$ & $102(85.7)$ & 1.00 & \multirow[t]{3}{*}{0.848} \\
\hline & GA & $37(12.2)$ & $17(14.3)$ & $1.20(0.65-2.22)$ & \\
\hline & AA & $0(0.0)$ & $0(0.0)$ & - & \\
\hline & $G$ & 569 (93.9) & 221 (92.9) & 1.00 & \multirow[t]{2}{*}{0.639} \\
\hline & $A$ & $37(6.1)$ & $17(7.1)$ & $1.18(0.65-2.14)$ & \\
\hline Eo3 $+2497 T>G$ & $\mathrm{TT}$ & $254(90.4)$ & $100(84.0)$ & 1.00 & \multirow[t]{3}{*}{0.190} \\
\hline \multirow[t]{4}{*}{ (rs23020009) } & TG & $27(9.6)$ & $19(16.0)$ & $1.79(0.95-3.36)$ & \\
\hline & GG & $0(0.0)$ & $0(0.0)$ & - & \\
\hline & $\mathrm{T}$ & 535 (95.2) & $219(92.0)$ & 1.00 & \multirow[t]{2}{*}{0.096} \\
\hline & G & $27(4.8)$ & $19(8.0)$ & $1.72(0.94-3.16)$ & \\
\hline
\end{tabular}

${ }^{a}$ Calculated from the translation start site, ${ }^{b}$ Logistic regression analyses were used for calculating OR $\left(95 \% \mathrm{Cl}\right.$; confidence interval), ${ }^{\mathrm{C}}$ Value was determined by Fisher's exact test or $\chi^{2}$ test from $2 \times 2$ contingency table.

Table 3. The haplotype frequencies of UC patients and controls in the eotaxin-2 and eotaxin-3.

\begin{tabular}{|c|c|c|c|c|c|}
\hline \multicolumn{3}{|c|}{ Haplotype } & \multicolumn{2}{|c|}{ Frequency $^{a}$} & \multirow{2}{*}{$P^{\mathrm{b}}$} \\
\hline$E o 2+179 T>C$ & $E o 2+275 C>T$ & $E o 3+2497 T>G$ & Control & UC & \\
\hline C & $\mathrm{T}$ & $\mathrm{T}$ & 0.606 & 0.550 & 0.214 \\
\hline $\mathrm{T}$ & C & $\mathrm{T}$ & 0.286 & 0.329 & 0.299 \\
\hline C & $\mathrm{T}$ & G & 0.028 & 0.074 & 0.024 \\
\hline C & C & $\mathrm{T}$ & 0.042 & 0.017 & 0.134 \\
\hline $\mathrm{T}$ & $\mathrm{T}$ & $\mathrm{T}$ & 0.027 & 0.025 & 0.845 \\
\hline $\mathrm{T}$ & C & G & 0.011 & 3.7E-07 & 0.447 \\
\hline $\mathrm{T}$ & $\mathrm{T}$ & G & $6.0 \mathrm{E}-21$ & 5.3E-03 & 0.139 \\
\hline C & C & G & $2.6 \mathrm{E}-23$ & 0.000 & - \\
\hline
\end{tabular}

${ }^{a}$ Values were calculated by EM algorithm with genotyped SNPs, ${ }^{b}$ Values were analyzed by permutation test. 
$+2497 T>G$ of eotaxin-3 gene in controls and UC patients because these genes are located on the same chromosome without any other interception. While eight haplotypes were identified with two major haplotypes, explaining more than $89 \%$ of distribution in controls, seven haplotypes in UC patients were identified out of eight possible haplotypes (Table 3 ). Although the haplotype frequencies by Eo $2+179 T>C$ and Eo $2+275 C>T$ of eotaxin- 2 gene between UC patients and controls were not significantly associated, the haplotype frequency of CTG between controls and UC patients was significantly different $(P=0.024)$.

\section{Discussion}

Generally, activated Th cells can differentiate to the development of at least two phenotypically and functionally distinct cell types, Th1 and Th2 cells (Mosmann et al., 1989; Abbas et al., 1996; Ho et al., 2002). Th1 cells produce the cytokines interferongamma (IFN- $\gamma$ ), interleukin-2 (IL-2) and lymphotoxin, which are commonly associated with cell-mediated immune responses against intracellular pathogens and induction of organ-specific autoimmune diseases (Kuchroo et al., 1995; Abbas et al., 1996). The cytokines produced by Th2 cells, such as IL-4, IL-5 and IL-10, are known to be associated with atopic and allergic diseases and are usually accompanied by increased production of $\lg \mathrm{G} 1$ and $\operatorname{lgE}$, and by activation of eosinophil and mast cells (Sher et al., 1992; Abbas et al., 1996; Hofstra et al., 1998). The balance between Th1 and Th2 cells is critical in immune response to pathogens, tumor antigens and allergens. Th1 and Th2 cells cross-regulate the differentiation of one another. In IBD, CD is associated with increased production of Th1 type cytokines, such as IFN- $\gamma$ and TNF- $\alpha$, whereas UC is associated with $T$ cells producing large amounts of Th2-type cytokine and eosinophil (Plevy et al., 1997; Farrell et al., 2002).

We previously identified a total of eight SNPs in eotaxin-2 and eotaxin-3 gene considered as the Th2 cell type cytokine, and suggested that Eo2 $+179 T>$ $C$ and Eo2 $+275 C>T$ of the eotaxin-2 and Eo3 $+2497 T>G$ of the eotaxin-3 were significantly associated with the susceptibility of allergic disease, such as asthma as well as allergic rhinitis (Chae et al., 2004; Chae et al., 2005). We analyzed the association of eotaxin-2 and eotaxin-3 gene in another allergic disease, UC, in this study and showed that the SNPs of eotaxin-2 and eotaxin-3 gene are associated with susceptibility to UC (Table 1). These results suggest that the SNPs of eotaxin gene family are extensively associated with susceptibility to allergic disease. The strong LDs among the SNPs of eotaxin-2 and eotaxin-3 gene suggested that eotaxin-2 and eotaxin-3 might work as a same block. It is very likely, considering that these genes are located on the same chromosome $(7 q 11.23)$ at distance of about $40 \mathrm{~kb}$ without any other interception.

In this study, our results suggest that the eotaxin-2 might be associated with susceptibility to UC. Although it is not clear that how eotaxin-2 can act in the susceptibility of allergic disease, our results demonstrate that eotaxin-2 is associated with susceptibility to various allergic disease.

\section{Acknowledgement}

This work was supported by a grant from the Korea Health 21 R\&D Project by Ministry of Health \& Welfare (01-PJ3-PG6-01GN09-003).

\section{References}

Abbas AK, Murphy KM, Sher A. Functional diversity of helper T lymphocytes. Nature 1996;383:787-93

Berkman N, Ohnona S, Chung FK, Breuer R. Eotaxin-3 but not eotaxin gene expression is upregulated in asthmatics 24 hours after allergen challenge. Am J Respir Cell Mol Biol 2001;24:682-7

Blumberg RS, Saubermann LJ, Strober W. Animal models of mucosal inflammation and their relation to human inflammatory bowel disease. Curr Opin Immunol 1999;11:648-56

Brown JR, Kleimberg J, Marini M, Sun G, Bellini A, Mattoli S. Kinetics of eotaxin expression and its relationship to eosinophil accumulation and activation in bronchial biopsies and bronchoalveolar lavage (BAL) of asthmatic patients after allergen inhalation. Clin Exp Immunol 1998;114:137-46

Chae SC, Lee YC, Park YR, Shin JS, Song JH, Oh GJ, Hong ST, Pae HO, Choi BM, Chung HT. Analysis of the polymorphisms in eotaxin gene family and their association with asthma, $\operatorname{lgE}$, and eosinophil. Biochem Biophys Res Commun 2004;320:131-7

Chae SC, Song JH, Pounsambath P, Yuan HY, Lee JH, Kim JJ, Lee YC, Chung HT. Molecular variations in Th1-specific cell surface gene Tim-3. Exp Mol Med 2004;30:274-8

Chae SC, Park YR, Oh GJ, Lee JH, Chung HT. The association of eotaxin-2 and eotaxin-3 gene polymorphisms in a Korean population with allergic rhinitis. Immunogenetics 2005;56:760-4

Dulkys $Y$, Schramm G, Kimmig D, Knoss S, Weyergraf A, Kapp A, Elsner J. Detection of mRNA for eotaxin-2 and eotaxin-3 in human dermal fibroblasts and their distinct activation profile on human eosinophils. J Invest Dermatol 2001;116:498-505

Farrell RJ, Peppercorn MA. Ulcerative colitis. Lancet 2002; 359:31-40 
Fuss IJ, Neurath M, Boirivant M, Klein JS, de la Motte C, Strong SA, Fiocchi C, Strober W. Disparate CD4+ lamina propria (LP) lymphokine secretion profiles in inflammatory bowel disease. Crohn's disease LP cells manifest increased secretion of IFN-gamma, whereas ulcerative colitis LP cells manifest increased secretion of IL-5. J Immunol 1996; 157:1261-70

Ho IC, Glimcher LH. Transcription: tantalizing times for T cells. Cell 2002;109:109-20

Hofstra CL, Van Ark I, Hofman G, Kool M, Nijkamp FP, Van Oosterhout AJ. Prevention of Th2-like cell responses by coadministration of IL-12 and IL-18 is associated with inhibition of antigen-induced airway hyperresponsiveness, eosinophilia, and serum IgE levels. J Immunol 1998;161: 5054-60

Kitaura M, Suzuki N, Imai T, Takagi S, Suzuki R, Nakajima T, Hirai K, Nomiyama H, Yoshie O. Molecular cloning of a novel human CC chemokine (eotaxin-3) that is a functional ligand of CC chemokine receptor 3. J Biol Chem 1999;274:2797580

Kuchroo VK, Das MP, Brown JA, Ranger AM, Zamvil SS, Sobel RA, Weiner HL, Nabavi N, Glimcher LH. B7-1 and B7-2 costimulatory molecules activate differentially the Th1/Th2 developmental pathways: application to autoimmune disease therapy. Cell 1995;10:707-18

Mosmann TR, Coffman RL. TH1 and TH2 cells: different patterns of lymphokine secretion lead to different functional properties. Annu Rev Immunol 1989;7:145-73

Patel VP, Kreider BL, Li Y, Li H, Leung K, Salcedo T, Nardelli B, Pippalla V, Gentz S, Thotakura R, Parmelee D, Gentz R, Garotta G. Molecular and functional characterization of two novel human C-C chemokines as inhibitors of two distinct classes of myeloid progenitors. J Exp Med 1997;185: 1163-72

Plevy SE, Landers CJ, Prehn J, Carramanzana NM, Deem $\mathrm{RL}$, Shealy D, Targan SR. A role for TNF-alpha and mucosal $T$ helper-1 cytokines in the pathogenesis of Crohn's disease. J Immunol 1997;159:6276-82
Sher A, Coffman RL. Regulation of immunity to parasites by $T$ cells and $T$ cell-derived cytokines. Annu Rev Immunol 1992;10:385-409

Shin HD, Kim LH, Park BL, Jung JH, Kim JY, Chung IY, Kim JS, Lee JH, Chung SH, Kim YH, Park HS, Choi JH, Lee YM, Park SW, Choi BW, Hong SJ, Park CS. Association of Eotaxin gene family with asthma and serum Total IgE. Hum Mol Genet 2003;12:1279-85

Shin HD, Park BL, Kim LH, Cheong HS, Lee IH, Park SK. Common interleukin 10 polymorphism associated with decreased risk of tuberculosis. Exp Mol Med 2005;37:128-32

Shinkai A, Yoshisue H, Koike M, Shoji E, Nakagawa S, Saito A, Takeda T, Imabeppu S, Kato Y, Hanai N, Anazawa H, Kuga T, Nishi T. A novel human CC chemokine, eotaxin-3, which is expressed in IL-4-stimulated vascular endothelial cells, exhibits potent activity toward eosinophils. J Immunol 1999;163:1602-10

Targan SR, Deem RL, Liu M, Wang S, Nel A. Definition of a lamina propria $T$ cell responsive state. Enhanced cytokine responsiveness of $T$ cells stimulated through the $\mathrm{CD} 2$ pathway. J Immunol 1995;154:664-75

Watanabe K, Jose PJ, Rankin SM. Eotaxin-2 generation is differentially regulated by lipopolysaccharide and IL-4 in monocytes and macrophages. J Immunol 2002;168:1911-5

Yang M, Hogan SP, Mahalingam S, Pope SM, Zimmermann N, Fulkerson P, Dent LA, Young IG, Matthaei KI, Rothenberg ME, Foster PS. Eotaxin-2 and IL-5 cooperate in the lung to regulate IL-13 production and airway eosinophilia and hyperreactivity. J Allergy Clin Immunol 2003;112:935-43

Ying S, Meng Q, Zeibecoglou K, Robinson DS, Macfarlane A, Humbert M, Kay AB. Eosinophil chemotactic chemokines (eotaxin, eotaxin-2, RANTES, monocyte chemoattractant protein-3 (MCP-3), and MCP-4), and C-C chemokine receptor 3 expression in bronchial biopsies from atopic and nonatopic (intrinsic) asthmatics. J Immunol 1999;163:6321-9 